\title{
DIAGNOSTIC AND SURGICAL APPROACH TO PRENATALLY DETECTED URINARY TRACT ANOMALIES
}

\author{
Mile Petrovski \\ University Clinic of Pediatric Surgery, Medical Faculty, Skopje, R. Macedonia \\ Corresponding Author: Mile Petrovski, University Clinic of Pediatric Surgery, Medical Faculty, Skopje, R. \\ Macedonia; e-mail: milep22@yahoo.com
}

\begin{abstract}
Regular ultrasound examinations carried out in the second trimester of pregnancy help in detecting many anomalies in the fetal urinary tract. Their percentage ranges from $1 \%$ to $3 \%$ of all controlled pregnancies. There is a wide spectrum of anomalies that affect the urinary tract, but the most significant are: uretero/hydronephrosis (unilateral or bilateral), kidney agenesis, dysplastic kidney, polycystic and multicystic kidneys, anomalies of ascent, anomalies of kidney rotation or fusion, bladder exstrophy, posterior urethra valve etc.

Many of these anomalies do not have impact either on urine flow or on kidney function and hence they can be qualified rather as a condition than as a disease. At the same time, most of the hydronephroses that are seen prenatally are being resolved spontaneously, and they are not detected neither presented postnatally as uretero/hydronephroses of unobstructed type and do not require surgical treatment. Only one tenth of these anomalies are subject to active surgical treatment.

Therefore, the assessment of these conditions should be done by a specialized team, who will make adequate therapeutic decisions based on clinical guidelines, as well as will advise the parents on the future clinical implications of the detected anomaly.
\end{abstract}

Keywords: prenatally ultrasound examinations, urinary tract anomalies, treatment

\section{Introduction}

The basic function of the kidney is to produce protein free ultra-filtrate (urine) that contains adequate quantity of water, electrolytes and end products of the metabolism, by which homeostasis of the human organism is actively maintained. In addition, the kidney produces two hormones, renin and angiotensin, and at the same time it participates in the metabolism of vitamin D. The function of the urinary tract is to collect and eliminate the produced urine.

When there are structural disorders along the urinary tract that obstruct urine flow, there are preconditions for development of obstructtive uropathy. Thus, the term obstructive uropathy is defined as a damage of the kidney parenchyma when there is a presence of obstruction at any level of the urinary tract [1].
The most significant consequence of the upper urinary tract obstruction is dilatation of the collecting system - hydronephrosis. Since dilatation of the renal pelvis and calyces may be present without obstruction, the term hydronephrosis should be used as a descriptive, anatomic entity, which defines only increasing - dilatation of the collecting system of the kidney [2].

The urinary system obstruction is one of the most common entities encountered by pediatric urologists. Despite the clear definition which provides easy recognition of the effects of chronic obstruction by the appearance of hydronephrosis, parenchymal atrophy and poor kidney function, these features also appear in conditions when morphologic disorders appeared during embryonic development, which have afterwards been resolved and hence the obser- 
ved kidney does not have to be in the condition of obstruction [3].

\section{Diagnostic procedures}

\section{Ultrasound Scan (US)}

Prenatal ultrasound examinations

Fetal urine production begins between 10 and 12 weeks of gestation. The largest quantity of the urine participates in the volume of amniotic fluid and it is an essential factor for lung development in the fetus. (3) Normal kidney is visualized from 18 to 20 weeks of pregnancy, a period convenient for routine ultrasound examinations. In this period, dilatation of the urinary tract (as indirect sign of obstruction) can be detected in conjunction with some other structural anomalies and oligohydramnios, which suggest impaired kidney function [4, 5]. Griglin [6] and Blyth [7] have introduced classification of hydronephrosis grading. Coelho [8] applies classification that has a predictive value for postnatal hydronephrosis manifestation: in the second trimester - mild grade if pelvic anteroposterior diameter (APD) ranges from 4 to 7 $\mathrm{mm}$, moderate if APD is from 7 to $10 \mathrm{~mm}$ and severe if APD is over $10 \mathrm{~mm}$. In addition, structural anomalies (cystic formations, fusion of kidneys etc.) can be detected while if the bladder is not visualized on repeated controls, there is a doubt about its exstrophy. Cases with moderate and severe grade of hydronephrosis should also be evaluated in the third trimester of pregnancy (Fig. 1).

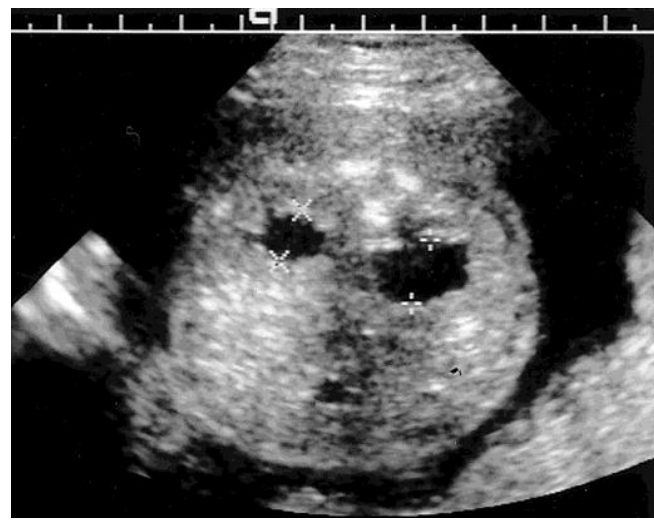

Fig. 1 - Prenatally diagnosed bilateral hydronephrosis

Postnatal ultrasound examinations

Although kidney function cannot be assessed by ultrasound, numerous and valuable pieces of information can be obtained, among which are: morphology, form, size and position of the kidney, then echogenicity; parenchymal thickness; uretero/hydronephrosis. Dilatation along the urinary tract is determined according to hydronephrosis grading system in five grades (from 0 to 4) according by the Society for Fetal Urology (SFU) [9].

\section{Radiological investigations}

\section{Excretory urography}

Excretory urography is the oldest method for diagnosis of hydronephrosis. This technique provides excellent data about morphology and partly, however not adequately quantified data about the function of the obstructed kidney. Its application is limited in current clinical practice.

Micturating cystourethrography (MCUG)

MCUG is performed in order to confirm or exclude subvesical obstruction as well as the presence of vesicoureteral reflux (VUR) (Fig. 2).

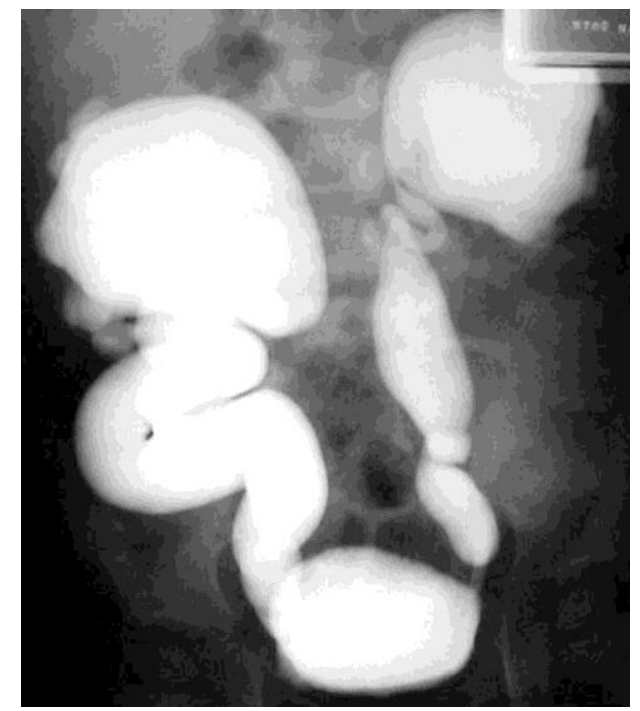

Fig. 2 - MCUG: Bilateral vesicoureretral reflux

Imaging techniques: computerized tomography and magnetic resonance

Computed tomography (CT) has a role in complementary explanation of more complex anomalies where hydronephrosis is present, such as duplex canal system, solitary kidneys, crossed ectopia etc.

By applying MRI urography as a nonionizing technique which aids in visualization of the whole urinary tract morphology, the CT use has decreased. At the same time, the application of gadolinium, bound to DTPA through a software system, the functional ability of the kidney can be seen [10] (Fig. 3). 


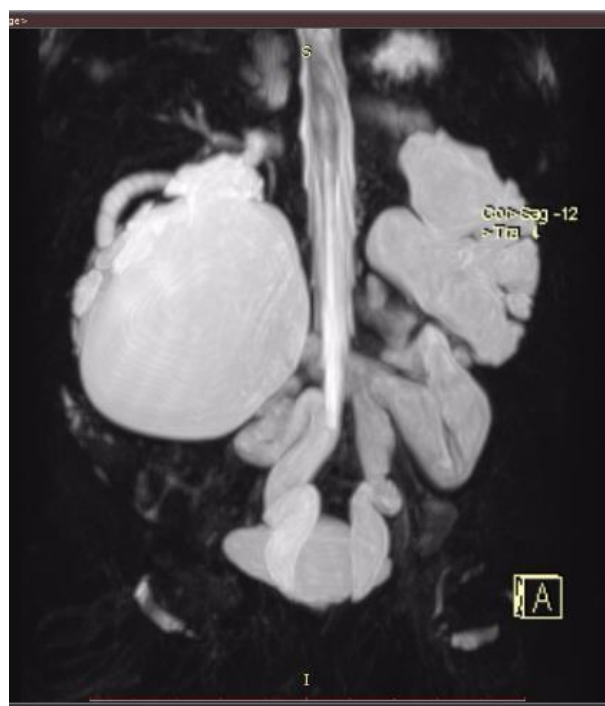

Fig. 3 - MRI urography (Bilateral UPJ stenosis and UPJ stenosis on right side)

Prenatal MR is indicated in precisely selected cases.

\section{Radioisotopic investigations}

Nuclear-medical methods are considered as techniques of primary importance for initial diagnosis and monitoring/screening of renal diseases in children. They are highly-sensitive techniques that enable early detection of diseases. Nuclear medicine provides unique functional and anatomical information by relatively low-dose radiation (Fig. 4).

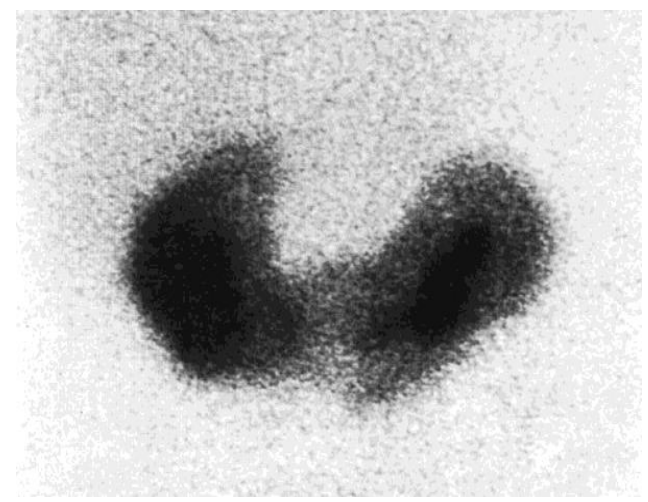

Fig. 4 - DMSA renal scan: Horseshoe kidney

Dynamic renography

Diuretic radioisotope renography (DRRG) has enormous role in diagnosing the obstructtive uropathies. DRRG is a physiologic study, which estimates the possibility of the kidney to respond to the diuretic-induced volume change. Analyzing the data obtained by DRRG the presence of obstruction is estimated by the model of radio-renogram curve by $\mathrm{T} / 2$ (the time when
$50 \%$ of the tracer of the zone of interest is eliminated). In addition, the relative function (percentage of glomerular filtration rate - GFR) of the kidneys is determined [11].

Renal cortical scintigraphy is safe and practical imaging technique for initial evaluation and follow-up/monitoring of children with cortical renal impairment. This technique aids in determining parenchymal volume without interference of radiotracer from collecting system [12].

\section{Classicifaction}

The following classification of congenital ureteral anomalies is based more on structure rather than on functional disorders [13].

\section{A. Kidney}

- $\quad$ Anomalies of number

$>$ Agenesis (bilateral, unilateral)

$>$ Supernumerary kidney

- Anomalies of volume and structure

$>$ Hypoplasia

$>$ Multicystic kidney

$>$ Polycystic kidney (infantile, adult, medullary cystic disease, other cystic diseases)

- Anomalies of ascent

$>$ Ectopia: thoracic, proximal, pelvic, crossed (with or without fusion)

- Anomalies of form and/or fusion

$>$ Crossed ectopia with or without fusion

$>$ Unilateral fused kidney (Sigmoid or Sshaped kidney, L-shaped kidney, disc-like kidney, horseshoe kidney)

- Anomalies of rotation

$>$ Incomplete, excessive and reverse

- Anomalies of renal vasculature

$>$ Aberrant, accessory, or multiple vessels; renal artery aneurysm; arteriovenous fistula

- Anomalies of the collecting system

$>$ Calyx and infundibulum

$\checkmark$ Calyceal diverticulum, hydrocalyx, megacalyx, extrarenal calyx.

$>$ Pelvis

$\checkmark \quad$ Exstrarenal pelvis, bifid pelvis, pyeloureteral stenosis.

B. Ureter

- $\quad$ Hydroureter (megaureter)

$>$ Obstructed

$>\quad$ Vesicoureteral reflux (VUR) 
$>$ Obstruction + VUR

$>$ Unobstructed, nonrefluxing

- Anomalies in entering the urinary bladder

- $\quad$ Ureteral duplication

- Ureterocele

C. Urinary bladder

- $\quad$ Bladder exstrophy

- Neurogenic urinary bladder (primary, secondary)

D. Urethra

- Posterior urethral valve

- Posterior urethral diverticulum

- Hypospadias

- $\quad$ Epispadias

In general, functional disorders as a result of congenital urinary tract anomalies affect the normal flow of urine. First of all, obstructions that appear lead to dilatation of the urinary system with subsequent loss of renal function.

The most common classification of functional dysfunction of the urinary tract is as follows:

\section{A. Upper urinary tract}

- Obstruction of pyeloureteral segment (hydronephrosis) (Fig. 5)

- Obstruction of ureterovesical junction (ureterohydornephrosis) (Fig. 6)

B. Lower urinary tract

- Urinary bladder (unilateral or bilateral ureterohydronephrosis)

- Subvesical obstruction (bilateral ureterohydronephrosis)

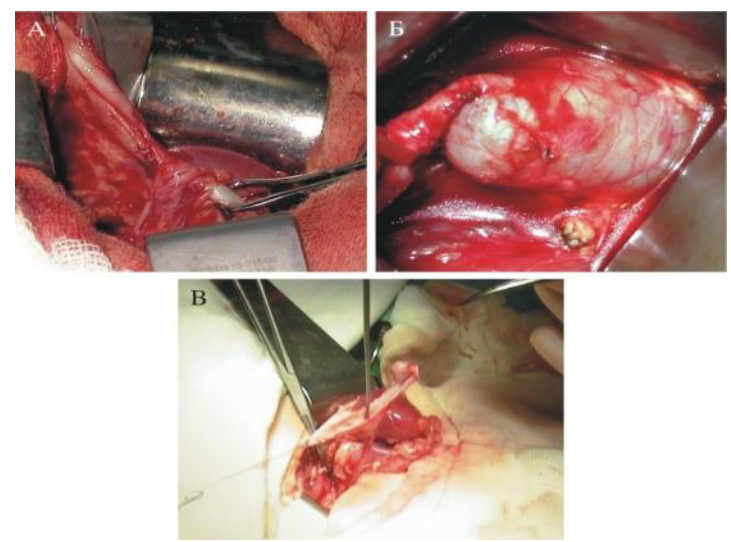

Fig. 5 - Ureteropelvic junction obstruction (A. Vas Aberans; B. High insertion; B. Stenosis)

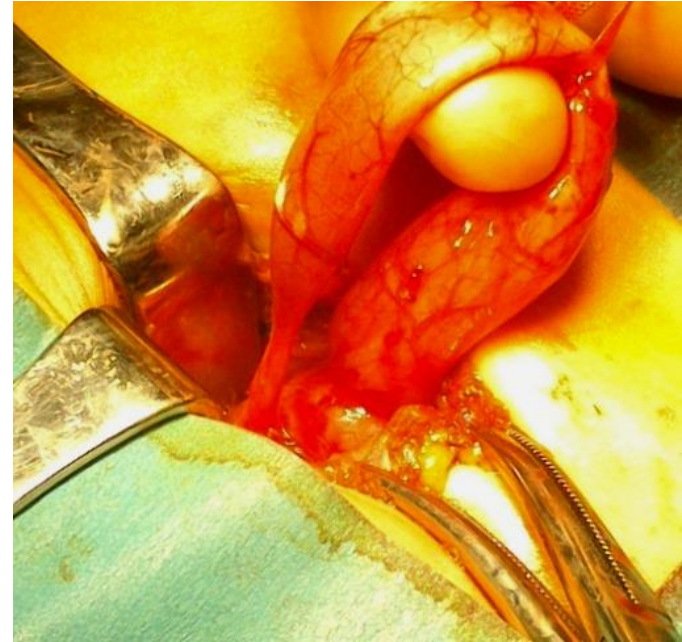

Fig. 6 - Prevesical ureteric stenosis

Hydornephrosis/ureterohydronephrosis

Hydronephrosis is a descriptive, anatomic entity defining dilatation of the renal collecting system. Chronic renal obstruction leads to onset of hydronephrosis, parenchymal atrophy and poor renal function. Obstruction causes hydronephrosis and hydronephrosis is not an equivalent to obstruction. Most often, nonobstructed uretero/hyronephrosis is a result of a spontaneously or surgically managed developmental anomaly or it is a diuretic phenomenon [14].

Distinction between obstructive and nonobstructive processes is based on the following facts:

- Unobstructed urinary tract transports urine throughout the entire physiologic range, without significant deformation changes and without increase in intraluminal pressures that would cause renal failure impairment.

- Obstructed system is more efficient in transporting small volumes than large ones [15].

To make a correct diagnosis a number of anatomic and functional investigations (US, MRI, MCUG, radioisotope methods) have to be conducted.

\section{Pathophysiology of the obstructed kidney}

Obstructive uropathy produces obstructtive nephropathy via a hemodynamic cascade reaction that causes ischemic injury. Preglomerular arteriolar vasoconstriction is mediated by the renin-angiotensin system. Animal studies have shown that this system increases an- 
giotensin-dependent vascular tonus of the obstructed kidney and decreases that of the opposite kidney, thus explaining the compensatory hypertrophy of the healthy kidney.

Partial ureteral obstruction causes activetion of other vasoactive substances: thromboxane- $A_{2}$, nitric monoxide and other eicosanoids. Other factors that cause kidney lesion are: 1. Mediators of inflammatory response; 2 . Cellular apoptosis (programmed cellular death modulated by the epidermal growth-factor); 3 . Cytokine growth-factor $\beta$ (initiates interstitial fibrosis); 4. Activation of the kallikrein-kinin system (impairs sodium metabolism); 5. Complexity in the pathophysiology [16-19].

\section{Pathohistology of the obstructed kidney}

In the beginning the dilatation of collecting tubules as well as deposition of fibroblasts and macrophages are predominating in the patho-anatomic substrate. Later, the collagen is transformed into fibrous tissue, manifested as interstitial and tubular fibrous degeneration, and in the end glomerular sclerosis develops, hence the entire functional kidney capacity is decreased $[1,20]$.

\section{Incidence}

Hydronephrosis is prenatally detected in $1 \%-3 \%$ of all controlled pregnancies, and $50 \%$ of them are verified postnatally. For comparison: the incidence of the most commonly surgically treated anomaly (pyelo-ureteral obstruction) is $1: 1500$ infants. About $10-20 \%$ of prenatally detected urinary anomalies require postnatal surgical treatment [21].

\section{Postnatal approach to infants with prenatally detected anomalies of the urinary tract}

By rule and due to the neonate's physiology the postnatal ultrasound is done the $3^{\text {rd }}$ day after birth at the earliest. Early exams might underestimate or might not detect the degree of hydronephrosis [22, 23].

\section{Treatment at tertiary level}

In severe cases the neonate should be assessed immediately after birth by a nephrology/urology team of experts. Urgent series of US exams, determination of electrolytes, urea and blood creatinine are recommended in these infants.

This group comprises infants with the following anomalies:

- Abnormal urinary bladder and/or history of oligo/anhydramnios;

- Severe form of bilateral ureterohydronephrosis (APD > $20 \mathrm{~mm}$ );

- Solitary kidney with expressed dilatetion of the upper urinary tract;

- Bilateral hypoechogenic kidneys;

- Autosomal recessive polycystic kidney disease (large "bright/echogenic" kidneys).

\section{Early consultation with a nephrologist/urologist}

It is necessary to make US in the second week after birth.

Newborns with the following anomalies belong to this group:

- Severe unilateral hydronephrosis (APD $>20 \mathrm{~mm}$ ), with or without dilated ureter;

- Bilateral hydronephrosis (APD>10 mm);

- Large multicystic kidney (>6 cm);

- Multicystic kidney with contra-lateral ureteral dilation;

- Duplex kidney with ureterocele.

\section{Antibiotic prophylaxis}

Antibiotics (trimetroprim $2 \mathrm{mg} / \mathrm{kg}$ in the evening) are to be given to the newborns with these features:

- Abnormal urinary bladder and/or history of oligo/anhydramnios;

- Bilateral hydronephrosis (APD>10 mm);

- Duplex kidney with ureterocele;

- Multicystic kidney with anomaly in the opposite kidney and ureter.

The following cases do not require antibiotic prophylaxis.

- Moderate degree of hydronephrosis;

- Multicystic kidney with normal contralateral/opposite kidney.

\section{Regular consultations with a pediatrician/nephrologist}

It is recommended to make US the first month after birth, and control visits at 3 to 6 months in the following cases:

- Moderate hydronephrosis with these characteristics: 
- Unilateral pelvic dilatation smaller than $15 \mathrm{~mm}$;

- Bilateral pelvic dilatation smaller than $10 \mathrm{~mm}$;

- Normal calyces;

- Normal echogenic kidney;

- Normal length of the kidney;

- Normal opposite kidney;

- Absence of ureteral dilation;

- Normal urinary bladder.

- Multicystic kidney with normal contralateral/opposite kidney (necessary verification at 6-month-age with DMSA radioisotope scan).

\section{Regular consultations with a family pediatrician}

Newborns who have been diagnosed with a minor anomalies of the urinary tract, including hydroneprhosis that has withdrawn during control prenatal scans, have to be taken to their family pediatricians for regular check-ups.

\section{Additional investigations}

In cases of suspicion of subvesical obstruction or vesicoureteral reflux micturating urethrocystography has to be conducted one month after birth. Diuretic radioreniogram is advised in order to define the existence of pyeloureteral or ureterovesical junction obstruction.

\section{Discussion and conclusion}

The incidence of urinary tract anomalies detected by prenatal screening is extremely high (up to 3\%). This piece of information causes anxiety in parents, with suspicion of insecure future for the fetus. Due to insufficient knowledge medical professionals who are not very familiar with this problem can increase the suspicions in the future parents-to-be.

It is known that a large number of anomalies (ectopia, malrotation, fusion of the kidneys) do not affect urine drainage, and hence do not damage kidney function. Therefore, they are to be defined as a condition rather than a disease. In more than $50 \%$ of cases, prenatal hydronephrosis is not detected postnatally. Additionally, quite a large number of postnatally detected hydronephrosis are being selfresolved during the embryonic development.

On the other hand, there are conditions that require active surgical treatment (all obstructions at the level of the upper and lower uri- nary tract). Some anomalies (exstrophy of urinary bladder, posterior urethral valve) ask for a long-term and uncertain treatment, and even in some series they are a cause for abortion (in $25-50 \%$ of cases). Overall, less than $10 \%$ of prenatally detected anomalies require active surgical treatment (Fig. 7).

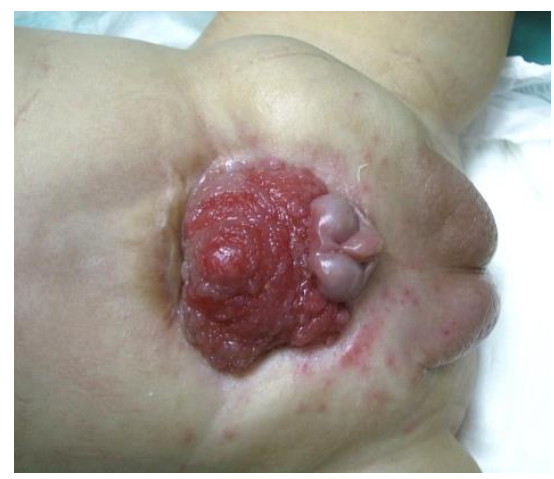

Fig. 7 - Vesical exstrophy

These conditions have to be subject of a team approach (gynecologist - perinatologist, pediatrician - neonatologist/nephrologist, pediatric surgeon/urologist). Thus, it is necessary to prepare a clinical guide (algorithm). This is the only way how we can reach the ideal: not a single unnecessary surgery or a single lost kidney.

Parents should consult and counsel with the members of the expert team in order to make quality-informed decisions about the future of their children.

\section{REFERENCES}

1. Gulmi FA, Felsen D, Vaughan ED. Pathophysiology of urinary tract obstruction. In: Walsh PC, Retik BA, Vaughan ED, Wein AJ, editors. Campbell's Urology. $8^{\text {th }}$ ed. CD-ROM. Philadelphia: Saunders; 2003.

2. Saunders Koff SA. Pathophysiology of ureteropelvic junction obstruction. Urol Clin North Am. 1990; 17: 263-72.

3. Nguyen HT, Kogan BA. Upper urinary tract obstruction: experimental and clinical aspects. $\mathrm{Br} \mathrm{J}$ Urol. 1998; 81: 13-21.

4. Freedman ER, Rickwood AMK. Prenatally diagnosed pelviureteric junction obstruction: a benign condition? J Pediatr Surg. 1994; 29: 769-72.

5. Shokeir AA, Nijman RJM. Antenatal hydronephrosis: changing concepts in diagnosis and subsequent managemnet. BJU Int. 2000; 85: 987-94.

6. Grignon A, Filiatrault D, Hoinsy Y. Uretero pelvic junction stenosis, antenatal ultrasonographic diagnosis, postnatal investigation and follow up. Radiology. 1986; 160: 649-51. 
7. Blyth B, Snyder HM, Ducket JF. Antenatal hydronephrosis and subsequent managemnet. J Urol. 1993; 149: 693-8.

8. Coelho GM, Bouzada MC, Pereira AK, Figueiredo BF, Leite MR, Oliveira DS, Oliveira EA. Outcome of isolated antenatal hydronephrosis: a prospective cohort study. Pediatr Nephrol. 2007; 22: 1727-34.

9. Fernbach SK, Maizels M, Conway JJ. Ultrasound grading of hydronephrosis: introduction to the system used by the Society for Fetal Urology. Pediatr Radiol. 1993; 23: 478-80.

10. Cerwinka WH, Damien Grattan-Smith J, Kirsch AJ. Magnetic resonance urography in pediatric urology. J Pediatr Urol. 2008; 4: 74-82.

11. Piepsz A, Ham HR, Roland JH, Froideville JL, Kintheart J, Hall M, Verboven M, Collier F. Technitium-99-m DMSA imaging and the obstructed kidney. Clin Nucl Med.1986; 11: 389-9l.

12. Kullendorf CM, Evander E. Renal parenchymal damage on DMSA-scintigraphy in pelviureteric obstruction. Scand J Urol Nephrol. 1989; 23: 127-30.

13. Shapiro E, Bauer SB, Chow JS. Anomalies of Upper Urinary Tract. In: Kavousii LR, Novick AC, Partin AW, Petres AC, editors. Campbell-Walsh Urology. $10^{\text {th }}$ ed. Philadelphia: Elsevier-Saunders; 2012. p. 3123-61.

14. Flashner SC, King LR. Ureteropelvic junction. In: Kelalis PP, King LR, Belman AB, editors. Clinical pediatric urology. Philadelphia: W. B. Saunders; 1992. p. 693-723.

15. Weiss RM. Obstructive uropathy: pathophysiology and diagnosis. In: Kelalis PP, King LR, Belman AB, editors. Clinical pediatric urology. Philadelphia: W. B. Saunders; 1992. p. 664-82.

16. Chevalier RL, Thornhill BA. Ureteral obstruction in the neonatal guinea pig: interaction of sympathetic nerves and angiotensin. Pediatr Nephrol. 1995; 9: 441-6.

17. Yanagisawa H, Morrissey J, Morrison AR, Klahr H. Eicosanoid production by isolated glomeruli of rats with unilateral ureteral obstruction. Kidney Int. 1990; 37: 1528-35.

18. Schreiner GF, Harris KP, Purkerson ML, Klahr S. Immunological aspects of acute ureteral obstruction: immune cell infiltrate in the kidney. Kidney Int. 1988; 34: 487.

19. Kennedy WA, Buttyan R, Sawczuk IS, et al. Epidermal growth factor suppresses renal tubular apoptosis following ureteral obstruction. Urology. 1997; 49: 973-80.

20. Restrepo N, Kess-Folts D, Ding G. Tubulointerstitial macrophages, transforming growth factorbeta, and monocyte chemoattractant peptide (MCP)1 after unilateral ureteral obstruction. J Am Soc Nephrol. 1993; 4: 826-33.

21. Carr MC. Anomalies and surgery of the ureteropelvic junction in children. In: Walsh PC, Retik BA, Vaughan ED, Wein AJ, editors. Campbell's Urology. $8^{\text {th }}$ ed. CD-ROM. Philadelphia: Saunders; 2003.

22. Sinha A, Bagga A, Krishna A, Bajpai M, Srinivas $\mathrm{M}$, et al. Revised Guidelines on Management of
Antenatal Hydronephrosis. Indian Pediatr. 2013; 50: 215-31.

23. Kirwan D. NHS Fetal Anomaly Screening Programme. 18 to 20 Weeks Fetal Anomaly Scan National Standards and Guidance for England. NHS Fetal Anomaly Screening Programme; 2010.

Резиме

\section{ДИЈАГНОСТЧКИ И ХИРУРШКИ ПРИСТАП КОН ПРЕНАТАЛНО ДЕТЕКТИРАНИТЕ АНОМАЛИИ НА УРИНАРНИОТ ТРАКТ}

\section{Миле Петровски}

Универзитетска клиника за детска хирургија, Медицински факултет, Скопје, Р. Македонија

Како резулатат на редовните ултразвучни контроли, во вториот триместар од бременоста се дијагностицираат голем број аномалии на уринарниот тракт на плодот. Нивниот процент се движи од $1 \%$ до $3 \%$ од сите контролирани болести. Постои широк спектар на аномалии што го засегаат уринарниот тракт, но најзначајни се следниве: уретеро/хидронефроза (еднострана или двострана), агенезија на бубрег, диспластичен бубрег, полицистични и мултицистични бубрези, аномалии во позиција, ротација или фузија на бубрезите, екстрофија на мочниот меур, валвула на задна уретра и др.

Голем број од овие аномалии не даваат реперкусии на уротекот, а со тоа ниту на функцијата на бубрегот, поради што можат да се квалификуваат како состојба, а не како болест. Воедно, поголемиот дел од хидронефрозите што се визуелизираат пренатално спонтано се разрешуваат, така што постнатално или не се детектираат или се презентираат како уретеро/хидронефрози од неопструктивен тип и не се предмет на хируршки третман. Само една десеттина од овие аномалии се предмет на активно оперативно лекување.

Затоа процената на овие состојби треба да е предмет на специјализиран тим, кој согласно со клиничко упатство ќе носи соодветни терапевтски решенија и квалитетно ќе ги советува родителите за идните клинички импликации на детектираната аномалија.

Клучни зборови: пренатални ултразвучни прегледи, аномалии на уринарниот тракт, третман 